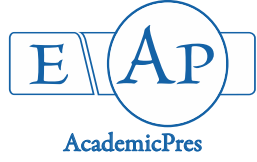

\title{
Age Susceptibility of Wistar Rats to Alloxan-Induced Diabetes: A Paradox
}

\author{
Patrick E.ABA*, Miracle N. EDEH \\ University of Nigeria, Department of Veterinary Physiology and Pharmacology, Nsukka, Enugu state, Nigeria; \\ Patrick.aba@unn.edu.ng (*correspondingauthor)
}

\begin{abstract}
Selection of appropriate ages of rats for experimental diabetes mellitus studies has been posing great challenges to researchers as the rats may either not come down with diabetes or may even die upon induction. This study investigated the influence of age as a possible factor affecting successful induction of diabetes mellitus in albino Wistar rats. One hundred male albino Wistar rats of varying ages weighing between $23.63 \pm 0.46 \mathrm{~g}$ and $279.00 \pm 27.00 \mathrm{~g}$ and assigned into ten (10) groups of ten rats per group were used for the study. Diabetes was induced in groups 1-9 consisting of rats aged 3, 5, 7, 9, 11, 13, 15, 17 and 19 weeks respectively by injecting $160 \mathrm{mg} / \mathrm{kg}$ of alloxan monohydrate intraperitoneally while group 10 rats (aged 12 weeks) served as normal control. Fasting blood glucose levels and the weights of the rats were determined on $0 \mathrm{~h}, 24 \mathrm{~h}, 48 \mathrm{~h}, 72$ $\mathrm{h}$ and $96 \mathrm{~h}$ post alloxan monohydrate injection. Body conditions and behaviors of the rats were subjectively scored. Results showed that rats in groups 3-9 came down with hyperglycemia $48 \mathrm{~h}$ post-alloxan injection. The body conditions and behaviors of groups 3 (aged 7 weeks) and 4 (Aged 9 weeks) rats compared very well $(\mathrm{p}<0.05)$ with those of the normal control rats. It was concluded that rats aged 7-9 weeks were most suitable for use in studies involving induction of experimental diabetes mellitus using alloxan monohydrate at the dose of $160 \mathrm{mg} / \mathrm{kg}$ intraperitoneally.
\end{abstract}

Keywords: animals; diabetogens; hyperglycemia; influence; length of time

\section{Introduction}

Diabetes mellitus is an important metabolic disease affecting both man and animal all over the world (Dewanjee et al., 2008). Two major types of diabetes mellitus are traditionally distinguished. Type 1 diabetes mellitus results from auto-immune destruction of the beta cells while type 2 is occasioned by insulin resistance followed by inability of beta cells to compensate for more insulin production (WHO, 1999). While type 1 is modeled by chemical ablation of the pancreatic beta cells, type 2 is tailored in obese animals with some degrees of insulin resistance (King, 2012).

Experimental diabetes mellitus may be induced by chemical or surgical methods (Etuk, 2010). Some of the chemicals used in inducing experimental diabetes include alloxan monohydrate and streptozotocin (Szkudelski et al., 1998). Researchers have proposed different mechanisms involved in the successful induction of experimental diabetes by these chemicals. It is in literature that alloxan monohydrate induces diabetes by destroying the pancreatic beta cells of the islet of langerhans through cascade of mechanisms involving redox pathways (Lenzen et al., 1996; Lenzen, 2008). This will result to reduction in insulin production thereby leading to accumulation of glucose beyond normal values in the blood (hyperglycemia). Similar mechanism of action has also been proposed for streptozotocin (Srinivasan and Ramarao, 2007).

Rodents such as rats and mice are among the animal models that have been used consistently in studies involving diabetes mellitus (Srinivasan and Ramarao, 2007). There are a lot of genetically manipulated rodents for diabetes studies (Etuk, 2010). Albino Wistar rats are very common laboratory rats for diabetes studies. They are outbred of albino rats with long ears, wide head and a tail length which is not as long as the body length. Wistar rats are more active than their Sprague dawley counterpart (Krinke, 2000).

Irregular observations of diabetes induction failures and different levels of success in induction in Wistar rats using alloxan monohydrate at the same dose in our laboratory constitute the driving force for this study. Some researchers submitted that successful induction of diabetes using alloxan depends on the dose of alloxan, animal species, route of administration and nutritional status of the animal (Federiuk, 2004).

There is dearth of information on the effect of age of Wistar rats on the success of diabetes induction using alloxan monohydrate. This study was therefore designed to investigate the influence of age as a possible factor affecting successful induction of diabetes in Wistar rats. 


\section{Materials and Methods}

\section{Animals}

One hundred (100) male albino Wistar rats of varying ages were obtained and bred in litters from the laboratory animal house of Veterinary Medicine Department, University of Nigeria, Nsukka Enugu State, Nigeria. All the rats were fed with Vital grower (Benin, Nigeria) feed and clean water ad libitum. They were housed in a standard stainless-steel cage. The experimental protocol used in this study was approved by the Ethics Committee of the University of Nigeria, Nsukka and conforms with guide to the care and use of animals in research and teaching of University of Nigeria, Nsukka, Enugu state, Nigeria (ECUN/174290).

\section{Experimental design}

The one hundred (100) male Wistar rats were assigned to ten (10) groups of ten (10) rats per group based on their ages. Groups 1-9 consist of rats aged 3 weeks, 5 weeks, 7 weeks, 9 weeks, 11 weeks, 13 weeks, 15 weeks, 17 weeks and 19 weeks respectively while rat's in-group 10 were aged 12 weeks. Diabetes mellitus was induced in rats of groups 1-9 by single intraperitoneal injection of alloxan monohydrate (Sigma Aldrich, UK) at the dose of $160 \mathrm{mg} / \mathrm{kg}$ (Venugopal et al., 1998) while rats in-group 10 served as normal control. The fasting blood glucose levels were determined before the injection of the alloxan monohydrate and subsequently 24 $\mathrm{h}, 48 \mathrm{~h}, 72 \mathrm{~h}$ and $96 \mathrm{~h}$ post alloxan monohydrate injection. The blood samples were obtained by tail snip. The weights of the rats were equally determined alongside with the fasting blood glucose values with the aid of electronic weighing balance (Mettler, Germany).

\section{Induction of experimental diabetes mellitus}

The method of Venugopal et al. (1998) was used. The rats in groups 1-9 were fasted (feed alone was withdrawn) for $16 \mathrm{~h}(5 \mathrm{pm}$ to $8 \mathrm{am})$ prior to diabetes induction. Induction was done by single intraperitoneal injection of $160 \mathrm{mg} / \mathrm{kg}$ of alloxan monohydrate. The fasting blood glucose levels were then monitored after $24 \mathrm{~h}, 48 \mathrm{~h}$ and $72 \mathrm{~h}$ (By 8 am daily) post induction. The rats were fasted for $16 \mathrm{~h}$ each time determination of fasting blood glucose (FBG) value was made. Rats with fasting blood glucose values greater than $126 \mathrm{mg} / \mathrm{dl}$ were considered diabetic (WHO, 1999).

\section{Preparation of alloxan monohydrate}

Alloxan monohydrate was prepared by dissolving a calculated quantity of the powder in a measured quantity of distilled water. The concentration of the alloxan monohydrate was determined by using the formular below guided by OECD's (Organisation of Economic Corporation and Development's) procedures (Erhirhie et al., 2014):

Concentration $(\mathrm{mg} / \mathrm{ml})=$ Weight of the Rat $(\mathrm{kg}) \times$ Dose of Alloxan monohydrate $(\mathrm{mg} / \mathrm{kg}) /$ Volume of alloxan monohydrate administered $(\mathrm{ml})$. The quantity of alloxan monohydrate given to the highest weighed rat was fixed at 1 $\mathrm{ml}$ to enable determination of the appropriate concentration for the study. Injection of alloxan monohydrate to the rats was done immediately upon reconstitution. Administration of alloxan monohydrate was done following the formula below:

Volume $(\mathrm{ml})=$ Weight of rat $(\mathrm{kg}) \times$ Dose of Alloxan monohydrate $(\mathrm{mg} / \mathrm{kg})$ / Concentration of alloxan monohydrate $(\mathrm{mg} / \mathrm{ml})$.

\section{Determination of weight}

The electronic weighing balance was adjusted to zero with beaker before the determination of the weights of the rats. Thereafter, rats were put each in a beaker and placed on the weighing balance where the reading was obtained digitally.

\section{Statistical analysis}

The data obtained were analyzed using One-way Analysis of Variance (ANOVA) with statistical package for social sciences (SPSS) version 20. Duncan's Multiple Range post hoc test was used to separate variant means. Probability values greater or equal to $0.05(\mathrm{p} \leq 0.05)$ were considered significant. The results were presented in tables as Mean $( \pm$ Standard Error of Mean).

\section{Results}

The FBG of all the rats in groups 3-9 were lower compared to their corresponding pre-induction values $24 \mathrm{~h}$ post alloxan injection. There were significant $(\mathrm{p}<0.05)$ increases in the FBG $48 \mathrm{~h}$ post induction compared to the pre-induction values. The increases persisted till the duration of the experiment. The FBG of the rats in group 10 (Control group) remained statistically similar until the duration of the experiment. Rats in groups 1 (aged 3 weeks) and 2 (aged 5 weeks) died $24 \mathrm{~h}$ post alloxan injection (Table 1).

Results indicated that the percentage increases in FBG levels of all the rats in all the groups were significantly $(p<0.05)$ higher than those of the rats in-group 10 (Control group) across the duration of the experiment. Rats in groups 6-9 had significantly higher FBG compared to others $24 \mathrm{~h}$ post induction. However, $96 \mathrm{~h}$ post induction, the percentage change in FBG levels of rats in-group 4 ( 9 weeks) were significantly $(p<0.05)$ higher than those of the other groups. The changes in the FBG of all the rats in groups 3-9 were statistically similar ( $>>0.05) 48 \mathrm{~h}$ and $72 \mathrm{~h}$ post induction (Table 2).

The body weight of the diabetic rats was significantly $(\mathrm{p}<0.05)$ reduced $96 \mathrm{~h}$ post induction when compared to their corresponding pre-induction values in most of the induced groups (Groups 3-8). However, the body weights of all the rats in groups 9 (19 weeks) and 10 (control) remained statistically similar $(p>0.05)$ till the end of the experiment (Table 3 ).

The percentage decreases in the body weight of the diabetic rats were statistically the same $96 \mathrm{~h}$ post induction. Significant percentage $(p<0.05)$ decreases in the body weights were observed in group 4 rats (Aged 9 weeks) $24 \mathrm{~h}$ $72 \mathrm{~h}$ post induction compared to the decreases in the weights of other diabetic rat groups. Percentage increases in the body weight of non-diabetic rats (Group 10) were recorded (Table 4). 
The body condition score was done according to in group 10 (Non-diabetic control) while those of the rats Hickman and Swan (2010). The general body condition in groups 6-9 were statistically the same (p>0.05) and were and behaviour of rats in groups 3 (aged 7 weeks) and 4 (aged better compared to the body condition of the rats in group 9 weeks) compared very well ( $p>0.05$ ) with those of the rats 5 (aged 11 weeks) (Table 5).

Table 1. Fasting blood glucose (FBG) levels of alloxan-induced diabetic rats of varying ages monitored for $96 \mathrm{~h}$

\begin{tabular}{|c|c|c|c|c|c|c|}
\hline \multirow{2}{*}{ Group } & \multirow{2}{*}{ Age (Weeks) } & \multicolumn{5}{|c|}{ Fasting blood glucose levels $(\mathrm{mg} / \mathrm{dl})$ post induction } \\
\hline & & Preinduction & $24 \mathrm{~h}$ & $48 \mathrm{~h}$ & $72 \mathrm{~h}$ & $96 \mathrm{~h}$ \\
\hline One & 3 & $90.33 \pm 3.33$ & - & - & - & - \\
\hline Two & 5 & $89.33 \pm 5.48$ & - & - & - & - \\
\hline Three & 7 & $96.00 \pm 0.57^{\mathrm{a}}$ & $60.00 \pm 2.88^{\mathrm{a}}$ & $466.33 \pm 13.30^{b}$ & $566.00 \pm 34.00^{\mathrm{b}}$ & $599.33 \pm 0.33^{\mathrm{b}}$ \\
\hline Four & 9 & $89.66 \pm 1.45^{a}$ & $65.66 \pm 2.84^{\mathrm{a}}$ & $490.00 \pm 100.00^{\mathrm{b}}$ & $528.33 \pm 16.75^{b}$ & $598.66 \pm 0.33^{b}$ \\
\hline Five & 11 & $95.66 \pm 1.85^{\mathrm{a}}$ & $55.33 \pm 2.40^{\mathrm{a}}$ & $584.33 \pm 12.01^{b}$ & $544.33 \pm 37.87^{\mathrm{b}}$ & $599.33 \pm 0.57^{b}$ \\
\hline Six & 13 & $95.33 \pm 3.17^{b}$ & $41.00 \pm 1.52^{\mathrm{a}}$ & $576.00 \pm 23.50^{c}$ & $599.33 \pm 0.33^{c}$ & $600.00 \pm 0.57^{\mathrm{c}}$ \\
\hline Seven & 15 & $94.66 \pm 2.40^{b}$ & $33.66 \pm 1.85^{\mathrm{a}}$ & $589.00 \pm 10.50^{c}$ & $599.66 \pm 0.66^{c}$ & $600.00 \pm 0.00^{c}$ \\
\hline Eight & 17 & $94.66 \pm 1.20^{\mathrm{b}}$ & $34.33 \pm 0.88^{\mathrm{a}}$ & $589.00 \pm 10.50^{c}$ & $599.00 \pm 0.57^{c}$ & $600.00 \pm 0.00^{c}$ \\
\hline Nine & 19 & $98.00 \pm 0.57^{b}$ & $42.33 \pm 1.70^{\mathrm{a}}$ & $553.66 \pm 45.83^{c}$ & $600.00 \pm 0.57^{c}$ & $599.66 \pm 0.33^{c}$ \\
\hline Ten & 12 & $94.00 \pm 6.02^{\mathrm{a}}$ & $95.00 \pm 2.00^{\mathrm{a}}$ & $101.00 \pm 6.08^{\mathrm{a}}$ & $101.00 \pm 5.50^{\mathrm{a}}$ & $99.33 \pm 0.88^{\mathrm{a}}$ \\
\hline
\end{tabular}

Table 2. Percentage changes in FBG levels of alloxan-induced diabetic rats of varying ages monitored for $96 \mathrm{~h}$

\begin{tabular}{|c|c|c|c|c|c|}
\hline \multirow{2}{*}{ Group } & \multirow{2}{*}{ Age (Weeks) } & \multicolumn{4}{|c|}{ Percentage change in fasting blood glucose levels post induction } \\
\hline & & $24 \mathrm{~h}$ & $48 \mathrm{~h}$ & $72 \mathrm{~h}$ & $96 \mathrm{~h}$ \\
\hline Three & 7 & $-37.00 \pm 2.88^{b}$ & $383.33 \pm 139.20^{\mathrm{b}}$ & $489.00 \pm 35.69^{b}$ & $523.66 \pm 4.05^{b}$ \\
\hline Four & 9 & $-26.66 \pm 2.33^{c}$ & $443.00 \pm 105.00^{\mathrm{b}}$ & $489.66 \pm 28.4^{\mathrm{b}}$ & $567.66 \pm 10.83^{c}$ \\
\hline Five & 11 & $-41.33 \pm 3.71^{b}$ & $511.00 \pm 20.99^{b}$ & $469.33 \pm 44.24^{\mathrm{b}}$ & $526.33 \pm 11.92^{b}$ \\
\hline Six & 13 & $-56.33 \pm 5.50^{a}$ & $506.00 \pm 38.97^{b}$ & $530.00 \pm 21.59^{b}$ & $530.00 \pm 21.59^{b c}$ \\
\hline Seven & 15 & $-64.00 \pm 2.08^{\mathrm{a}}$ & $522.00 \pm 5.50^{b}$ & $534.00 \pm 16.80^{\mathrm{b}}$ & $534.00 \pm 16.80^{\mathrm{bc}}$ \\
\hline Eight & 17 & $-63.00 \pm 0.57^{\mathrm{a}}$ & $521.00 \pm 7.76^{\mathrm{b}}$ & $532.66 \pm 7.68^{b}$ & $533.00 \pm 8.18^{\mathrm{bc}}$ \\
\hline Nine & 19 & $-56.33 \pm 1.85^{a}$ & $531.00 \pm 22.59^{b}$ & $512.00 \pm 4.04^{\mathrm{b}}$ & $511.66 \pm 3.75^{b}$ \\
\hline Ten & 12 & $10.00 \pm 4.16^{\mathrm{d}}$ & $7.00 \pm 2.00^{\mathrm{a}}$ & $7.33 \pm 3.28^{\mathrm{a}}$ & $8.00 \pm 6.00^{\mathrm{a}}$ \\
\hline
\end{tabular}

Different superscripts a,b, c, d along the same column indicate significant difference at $\mathrm{p}<0.05$

Table 3. Body weight of alloxan-induced diabetic rats of varying ages monitored for $96 \mathrm{~h}$

\begin{tabular}{|c|c|c|c|c|c|c|}
\hline \multirow{2}{*}{ Group } & \multirow{2}{*}{ Age (Weeks) } & \multicolumn{5}{|c|}{ Body weight (g) } \\
\hline & & Preinduction & $24 \mathrm{~h}$ & $48 \mathrm{~h}$ & $72 \mathrm{~h}$ & $96 \mathrm{~h}$ \\
\hline One & 3 & $23.63 \pm 0.46$ & - & - & - & - \\
\hline Two & 5 & $28.50 \pm 2.32$ & - & - & - & - \\
\hline Three & 7 & $67.50 \pm 1.70^{c}$ & $61.96 \pm 0.92^{\mathrm{b}}$ & $59.26 \pm 0.64^{\mathrm{ab}}$ & $57.68 \pm 0.33^{a}$ & $56.76 \pm 0.88^{a}$ \\
\hline Four & 9 & $90.40 \pm 1.18^{c}$ & $76.66 \pm 0.74^{b}$ & $72.86 \pm 1.39^{\mathrm{a}}$ & $71.33 \pm 1.20^{\mathrm{a}}$ & $70.00 \pm 1.01^{\mathrm{a}}$ \\
\hline Five & 11 & $125.63 \pm 4.52^{\mathrm{b}}$ & $112.33 \pm 5.36^{\mathrm{ab}}$ & $107.33 \pm 6.35^{a}$ & $107.66 \pm 3.71^{a}$ & $105.33 \pm 2.96^{a}$ \\
\hline Six & 13 & $155.56 \pm 3.24^{b}$ & $151.33 \pm 1.85^{\mathrm{b}}$ & $149.33 \pm 1.85^{b}$ & $139.00 \pm 0.57^{b}$ & $120.00 \pm 2.88^{\mathrm{a}}$ \\
\hline Seven & 15 & $189.00 \pm 8.62^{\mathrm{b}}$ & $191.00 \pm 0.57^{\mathrm{b}}$ & $186.66 \pm 3.52^{b}$ & $180.33 \pm 0.88^{b}$ & $160.33 \pm 18.70^{a}$ \\
\hline Eight & 17 & $251.30 \pm 11.57^{b}$ & $241.00 \pm 1.52^{\mathrm{ab}}$ & $239.66 \pm 0.66^{\mathrm{ab}}$ & $230.66 \pm 6.35^{\mathrm{ab}}$ & $212.66 \pm 18.88^{a}$ \\
\hline Nine & 19 & $276.36 \pm 31.66^{a}$ & $279.00 \pm 27.00^{a}$ & $271.33 \pm 24.37^{a}$ & $255.33 \pm 28.52^{\mathrm{a}}$ & $272.33 \pm 13.83^{\mathrm{a}}$ \\
\hline Ten & 12 & $146.03 \pm 7.06$ & $147.00 \pm 7.23^{\mathrm{a}}$ & $157.00 \pm 2.51^{a}$ & $158.66 \pm 2.33^{\mathrm{a}}$ & $163.33 \pm 14.52^{a}$ \\
\hline
\end{tabular}

Different superscripts a,b,c across the same row indicate significant difference at $\mathrm{p}<0.05$

Table 4. Percentage changes in body weight of alloxan-induced diabetic rats of varying ages monitored for $96 \mathrm{~h}$

\begin{tabular}{cccccc}
\hline \multirow{2}{*}{ Group } & \multirow{2}{*}{ Age (Weeks) } & \multicolumn{4}{c}{ Percentage change in body weight } \\
\cline { 3 - 6 } & & $24 \mathrm{~h}$ & $48 \mathrm{~h}$ & $72 \mathrm{~h}$ & $96 \mathrm{~h}$ \\
\hline Three & 7 & $-7.66 \pm 1.20^{\mathrm{bc}}$ & $-11.66 \pm 2.18^{\mathrm{ab}}$ & $-14.00 \pm 2.00^{\mathrm{ab}}$ & $-15.33 \pm 1.20^{\mathrm{a}}$ \\
Four & 9 & $-14.66 \pm 2.02^{\mathrm{a}}$ & $-19.00 \pm 1.52^{\mathrm{a}}$ & $-20.33 \pm 1.66^{\mathrm{a}}$ & $-22.02 \pm 2.08^{\mathrm{a}}$ \\
Five & 11 & $-10.00 \pm 1.52^{\mathrm{b}}$ & $-15.33 \pm 6.17^{\mathrm{b}}$ & $-13.66 \pm 6.35^{\mathrm{b}}$ & $-15.66 \pm 1.70^{\mathrm{a}}$ \\
Six & 13 & $-2.33 \pm 1.85^{\text {cd }}$ & $-3.67 \pm 2.33^{\mathrm{b}}$ & $-10.00 \pm 2.08^{\mathrm{b}}$ & $-22.66 \pm 2.18^{\mathrm{a}}$ \\
Seven & 15 & $-6.00 \pm 2.64^{\mathrm{bcd}}$ & $-6.33 \pm 1.20^{\mathrm{b}}$ & $-6.66 \pm 1.76^{\mathrm{b}}$ & $-15.66 \pm 11.25^{\mathrm{a}}$ \\
Eight & 17 & $-4.67 \pm 3.70^{\mathrm{bcd}}$ & $-4.66 \pm 3.66^{\mathrm{b}}$ & $-7.33 \pm 2.72^{\mathrm{b}}$ & $-15.00 \pm 3.50^{\mathrm{a}}$ \\
Nine & 19 & $1.33 \pm 1.33^{\mathrm{cd}}$ & $-3.67 \pm 2.02^{\mathrm{b}}$ & $-7.33 \pm 1.33^{\mathrm{b}}$ & $-12.66 \pm 4.66^{\mathrm{a}}$ \\
Ten & 12 & $0.003 \pm 0.003^{\mathrm{c}}$ & $7.67 \pm 6.22^{\mathrm{c}}$ & $9.00 \pm 6.65^{\mathrm{c}}$ & $11.66 \pm 8.74^{\mathrm{b}}$ \\
\hline
\end{tabular}


Table 5. Assessment of body and behavioral condition of alloxan-induced diabetic rats monitored for $96 \mathrm{~h}$

\begin{tabular}{|c|c|c|}
\hline Group & Age & Condition \\
\hline One & 3 & $0.00 \pm 0.00^{\mathrm{a}}$ \\
\hline Two & 5 & $0.00 \pm 0.00^{\mathrm{a}}$ \\
\hline Three & 7 & $3.75 \pm 0.25^{d}$ \\
\hline Four & 9 & $3.75 \pm 0.25^{d}$ \\
\hline Five & 11 & $2.00 \pm 0.40^{\mathrm{b}}$ \\
\hline Six & 13 & $2.75 \pm 0.25^{\mathrm{c}}$ \\
\hline Seven & 15 & $3.00 \pm 0.00^{c}$ \\
\hline Eight & 17 & $3.00 \pm 0.00^{c}$ \\
\hline Nine & 19 & $3.25 \pm 0.25^{\mathrm{cd}}$ \\
\hline Ten & 12 & $4.00 \pm 0.00^{d}$ \\
\hline
\end{tabular}

Different superscripts a,b, c, d along the same column indicate significant difference at $\mathrm{p}<0.05$

$0=$ Dead, $1=$ Moribund, $2=$ Weak and dull, $3=$ Weak and alert, $4=$ Agile and alert

\section{Discussion}

The study investigated possible influence of age of albino Wistar rats in the successful induction of experimental diabetes mellitus using alloxan monohydrate.

Twenty-four $(24 \mathrm{~h})$ hours post injection of alloxan monohydrate, the FBG levels of the induced rats (Groups 19) were appreciably lower than their corresponding preinduction values (Table 1). This may be consequent upon the effect of alloxan monohydrate on the pancreatic islet cells. Alloxan monohydrate has destructive effects on the islet cells of the pancreas. Researchers have reported that hypoglycemia is the first stage of alloxan-induced hyperglycemia (Lenzen et al., 1996; Lenzen, 2008). Influx of alloxan monohydrate via GLUT2 transporter into the pancreatic beta cell increases calcium ion concentration that destroys the beta cells and triggers overproduction of insulin that in turn leads to hypoglycemia (Kliber et al., 1996). Subsequently, the FBG of the rats in groups 3-9 increased significantly $(\mathrm{p}<0.05) 48 \mathrm{~h}$ through $96 \mathrm{~h}$ post alloxan injection (Table 1). Earlier researchers had reported hyperglycemia $48 \mathrm{~h}$ following alloxan injections (Tasaka $e t$ al., 1988; Lenzen, 2008). This may have resulted following exhaustion of insulin secretion by the glucose analogue, alloxan monohydrate (Kliber et al., 1996), thus leading to hyperinsulinemia and the attendant hyperglycemic episode. It is believed that within $24 \mathrm{~h}$ post-alloxan monohydrate administration, most of the beta cells of the islet of langerhans have been destroyed leading to release of more insulin into the circulation. This explains why there is hypoglycemia within this period. However, after $24 \mathrm{~h}$, insulin levels in the circulation begin to wane since the beta cells that secrete them have been appreciably destroyed thus leading to a gradual buildup of glucose in the blood (hyperglycemia). Rats in groups 1 (aged 3 weeks) and 2 (Aged 5 weeks) could not survive the initial hypoglycemic episode beyond $24 \mathrm{~h}$. We unarguably attributed the death of these groups of rats to hypoglycemia because at the point of death, their blood glucose levels were so low. This may be attributed either to the immature pancreas or due to overdose of the chemical (Alloxan monohydrate). We also opine that the tested dose $(160 \mathrm{mg} / \mathrm{kg})$ of alloxan administered may have also been responsible for the death. This goes a long way to also caution against the use of up to that dose in relatively immature rats like these ones.
Researchers reported that the dose of alloxan in rats should be between $40-200 \mathrm{mg} / \mathrm{kg}$ depending on the route of administration and the nutritional status of the animal (Szkudelski et al., 1998). They equally noted that alloxan has a narrow diabetogenic dose and that overdose could lead to death. Researchers have reported death of experimental goat following alloxan administration (Haghdoost et al., 2007).

The higher percentage increases in the FBG of all the diabetic groups compared to the non-diabetic normal control was attributed to the effect of alloxan monohydrate. Alloxan monohydrate is known to evoke a sudden rise in circulating insulin levels thereby leading to a corresponding decrease in the sugar levels (Lachin and Reza, 2012). Insulin is a pancreatic hormone involved in glucose metabolism. It literally 'drags' the circulating glucose into cells thereby reducing the plasma glucose levels. The glucose transporters are dependent on the insulin signaling. The body weights of the alloxanized rats were significantly $(p<0.05)$ reduced when compared to their corresponding pre-induction counterparts. This may have resulted from the effect of diabetes. Unexplained weight loss is a cardinal sign of diabetes mellitus (Cook and Plotnick, 2008). This unexplained weight loss however may be attributed to the fact that abnormal metabolism of carbohydrate, protein and fat accompany diabetes mellitus.

Observation of better body and behavioural conditions in the rats of 7-9 weeks old albino Wistar rats despite the high fasting glucose values when compared to the other older diabetic rats (aged 11-19 weeks) is paradoxical. However, it may be that at this age, the rats were better equipped to handle (metabolize) the drug, alloxan compared to the older rats. Alloxan has been reported to infiltrate other organs such as liver, kidney, brain following parenteral administration (Lee et al., 2010). The liver in particular is responsible for detoxification and biotransformation of xenobiotics. Probably the functional capacities of these organs (liver particularly) are at optimum at this age (7-9 weeks old rats) making them able to handle some deleterious effects due to alloxan administration. It is a well-known phenomenon that alloxan generates a lot of reactive oxygen species (ROS) which have oxidative and degenerative effects on body cells (Lachin and Reza, 2012; Rohilla and Ali, 2012). The body and behavioural conditions of 7-9 weeks rats compared very well to that of the normal control group. 


\section{Conclusions}

From the results of the experiment, it was concluded that while all the albino Wistar rats aged 7-19 weeks can be used for experimental diabetes induction, those aged 7-9 weeks appeared to be better candidates. Albino Wistar rats aged 3-5 weeks should not be alloxanized at $160 \mathrm{mg} / \mathrm{kg}$ for the purposes of induction of experimental diabetes as this could lead to massive mortality of the rats. Further studies could be performed to determine the appropriate dose of alloxan that can be used to induce diabetes in albino wistar rats aged 3-5 weeks.

\section{Conflicts of interest}

The authors declare that there are no conflicts of interest related to this article.

\section{References}

Cooke DW, Plotnick L (2008). Type 1 diabetes mellitus in pediatrics. Pediatric in Review29(11):37484.

Dewanjee S, Bose SK, Sahu R, Mandal SC (2008). Antidiabetic effect of matured fruits of Diospyros peregrine in alloxan induced diabetic rats. International Journal of Green Pharmacy 2(2):95-99.

Erhirhie EO, Ekene NE, Ajaghaku DL (2014). Guidelines on dosage calculation and stock solution preparation in experimental animals' studies. Journal of Natural Science Research 4(18):100-106.

Etuk EU (2010). Animal models for studying diabetes mellitus. Asian Journal of Experimental Biological Science 1(2):331-336.

Federiuk IF, Casey HM, Quinn MJ, Wood MD, Ward WK (2004). Induction of type 1 diabetes mellitus in laboratory rats by use of alloxan; route of administration, pitfalls, and insulin treatment. Comprehensive Medicine 54(3):252-257.

Haghdoost IS, Ghaleshahi AJ, Safi S (2007). Clinicopathological findings of diabetes mellitus by alloxan in goats. Comparative Clinical Pathology 16(1):53-59.

Hickman DL, Swan M (2010). Use of a body condition score technique to assess health status in a rat model of polycystic kidney disease. Journal of American Association of Laboratory Animal Science 49(2):155-159.
King AJ (2012). The use of animal models in diabetes research. British Journal of Pharmacology 166(3):877-894.

Kliber A, Szkudelski T, Chichlowska J (1996). Alloxan stimulation and subsequent inhibition of insulin release from in situ perfused rat pancreas. Journal of Physiology and Pharmacology $47(2): 321-328$.

Krinke GJ (2000). History, strains, and models. In: Bullock G, Bunton T (Series Ed). The Laboratory Rat (Handbook of Experimental Animals).Academic Press.

Lachin T, Reza H (2012). Antidiabetic effects of cherries in alloxan-induced diabetic rats. Recent Patents on Endocrine Metabolic and Immune DrugDiscovery 6(1):67-72.

Lee JH, Yang SH, Oh JM, Lee MG (2010). Pharmacokinetics of drugs in rats with diabetes mellitus induced by alloxan or streptozocin: comparison with those in patients with type I diabetes mellitus. Journal of Pharmacy and Pharmacology 62(1):1-23.

Lenzen S (2008). The mechanisms of alloxan- and streptozotocin-induced diabetes. Diabetologia 51(2):216-226.

Lenzen S, Tiedge M, Jorns A, Munday R(1996). Alloxan derivatives as a tool for the elucidation of the mechanism of the diabetogenic action of alloxan. In: Shafrir E. Lessons from Animal Diabetespp 113-122.

Rohilla A, Ali S (2012). Alloxan induced diabetes: Mechanism and effects. International Journal of Research in Pharmaceutical and Biomedical Science 3(2):819-823.

Srinivasan K, Ramarao P (2007). Animal models in type 2 diabetes research: an overview. Indian Journal of Medical Research 125(3):451-472.

Szkudelski T, Kandulska K, Okulicz M(1998). Alloxan in vivo does not only exert deleterious effects on pancreatic B cells. Physiological Research 47(5):343-346.

Tasaka Y, Inoue Y, Matsumoto H, Hirata Y (1988). Changes in plasma glucagon, pancreatic polypeptide and insulin during development of alloxan diabetes mellitus in dog. Endocrinology 35(3):399-404.

Venogopal PM, Prince PSM., Pari L (1998). Hypoglycemic activities of Syzigiumcumini seeds effect on lipid peroxidation in alloxan diabetic rats. Journal ofEthnopharmacology61(1):1-7.

WHO (1999). Definition, diagnosis and classification of Diabetesmellitus and its complications: A Report of WHO consultation Department of Non-communicable disease surveillance Geneva, Switzerland. 